\title{
Effect of Age at Castration on Beef Calf Performance ${ }^{1}$
}

\author{
Amie Imler, Todd Thrift, Matt Hersom, and Joel Yelich²
}

\section{Introduction}

Beef cow-calf producers use a variety of production practices on beef calves prior to weaning, at weaning, or post-weaning. Common practices include castration, identification, health management, dehorning, growth implant administration, and preconditioning. Implementing one or several of these management practices impacts the supply of calves available for beef production, as well as the quality and subsequent performance of calves in the stocker, feedlot, and harvesting segments (Avent, Ward, and Lalman 2002). Consequently, cow-calf producers can significantly impact the value of their calves through on-farm management (Schulz et al. 2010).

Castration, the process of removing or destroying the testicles, is a common management practice in beef cattle operations. Approximately $60 \%$ of U.S. beef cow-calf producers castrated their male calves prior to sale (USDANAHMS 2008). Producers choose to castrate calves before marketing for several reasons, with the primary reason being market demand and economics. Traditionally, steers have a distinct advantage in the marketplace over their intact contemporaries because steers fit within modern U.S. beef production systems and produce a more desirable carcass for consumers (Bretschneider 2005). Additionally, steers are preferred because intact bulls are more aggressive, increase the opportunity for injury to animals and people, and exhibit sexual behavior in the feedlot.
Although the practice of castration is widely used in the industry, the timing and method used for castration can vary considerably between operations. Factors that may impact castration timing include producer philosophy, product marketing claims, weather, and availability of resources such as facilities or labor. Some cattle producers believe that delayed castration improves growth in nursing calves. This belief is also endorsed by some castration tool manufacturers who claim that delayed castration creates significant weight gain advantages at weaning compared to calves castrated shortly after birth. Since producers are paid on a weight basis, most opt to market their calves at weaning. Consequently, differences in weaning weight can mean differences in profitability.

Industry recommendations generally advocate that calves be castrated as soon as possible after birth (Bretschneider 2005). The general belief is that castration in young, sexually immature calves elicits less of a stress response and reduces the risk of castration-associated blood loss and potential for infections (King et al. 1991; Lyons-Johnson 1998; Stafford and Mellor 2005). At the same time, many producers are concerned that castrating too early will reduce growth rates in bull calves from birth to weaning (Lehmkuhler 2003). Some research suggests that bulls gain slightly faster than castrates during the nursing phase (Klosterman et al. 1954; Marlowe and Gaines 1958).

However, other researchers propose those differences are because of improvements gained through genetic selection (Cundiff, Willham, and Pratt 1966).

1. This document is AN289, one of a series of the Department of Animal Sciences, Florida Cooperative Extension Service, Institute of Food and Agricultural Sciences, University of Florida. Original publication date March 2013. Visit the EDIS website at http://edis.ifas.ufl.edu.

2. Amie Imler, former graduate student, Department of Animal Sciences; Todd Thrift, associate professor, Department of Animal Sciences; Matt Hersom, associate professor, Department of Animal Sciences; and Joel Yelich, associate professor, Department of Animal Sciences; Florida Cooperative Extension Service, Institute of Food and Agricultural Sciences, University of Florida, Gainesville, FL 32611. 
Most research literature suggests that castrating calves shortly after birth has minimal to no effect on weaning weight. Glimp et al. (1971) assigned Hereford and Angus calves to be castrated either at birth, weaning, or left intact. Average daily gain during the pre-weaning period and 200-day adjusted weaning weight was not different across treatments. Calves castrated at birth gained $1.67 \mathrm{lbs} / \mathrm{day}$, while intact calves gained $1.61 \mathrm{lbs} /$ day and calves castrated at weaning gained $1.63 \mathrm{lbs} /$ day. Looper et al. (2005) also reported that bulls surgically castrated at birth or at weaning had similar adjusted 205-day weaning weights. Bailey, Probert, and Bohman (1966) compared the pre-weaning growth rate of bulls surgically castrated at approximately 3 months of age to calves left intact in two separate studies. Differences in pre-weaning growth rate and weaning weight were not significant among the two treatments in either study. Upon weaning at approximately seven months of age, bulls weighed $404 \mathrm{lbs}$, while steers weighed $400 \mathrm{lbs}$.

In contrast, Micol et al. (2009) reported that bulls castrated at 10 months of age had greater live weight gains from birth to weaning than bulls castrated at 2 months of age (2.33 vs. $2.22 \mathrm{lbs} /$ day, respectively). However, bulls castrated at 2 months of age gained faster than the 10-month castrates during the post-weaning ( 1.65 vs. $1.34 \mathrm{lbs} /$ day, respectively) and finishing ( 1.63 vs. $1.45 \mathrm{lbs} /$ day, respectively) phases of the trial, resulting in no weight gain differences over the entire trial period. Similarly, Knight et al. (2000) reported a lower pre-weaning growth rate in calves castrated at birth compared to calves castrated at 6 and 12 months of age. Calves castrated at birth gained $2.38 \mathrm{lbs} /$ day pre-weaning, while calves castrated at 6 and 12 months of age both gained $2.53 \mathrm{lbs} /$ day during this time. These differences did not result in significant live weight differences beyond 6 months of age.

Despite the perceived benefits of delayed castration, studies have demonstrated that both lightweight calf-fed and yearling calves castrated post-weaning have significantly reduced feedlot performance and health compared to calves purchased as steers (Berry et al. 2001; Knight et al. 1999). Additionally, evidence suggests that castration elicits a greater stress response in 5.5 month old calves than calves castrated at 1.5 months of age (Stafford and Mellor 2005). As the beef industry focuses more on the principles of animal welfare and the economics of efficiency, producers may find that the supposed benefits of delayed castration are far outweighed by its drawbacks.

\section{Florida Study}

A study in Florida was conducted to examine the issue of age at castration to determine if castration timing resulted in significant differences in growth rate and weaning weight in nursing calves. In addition, the study included a comparison between Angus and Brangus calves in the treatment groups to determine if there was a breed by castration effect. The study used 92 intact Angus and Brangus bull calves, which were born between December 18, 2009, and March 28, 2010. Cow-calf pairs were divided by calf birth date, calf breed (Angus or Brangus), and dam age (2 year old or $>2$ years old), and then randomly assigned to one of two treatment groups, early $(n=51)$ and late $(n=41)$ castration.

In the study, all bull calves were surgically castrated using the Newberry Knife to incise the scrotum, and traction was used to remove the testes from the scrotum. Early castrates ( $\mathrm{n}=23$ Angus; $\mathrm{n}=28$ Brangus) were a mean age of 36 days (range of 3-73 days) at castration on March 1, 2010, and April 23, 2010. Late castrates ( $\mathrm{n}=15$ Angus; $\mathrm{n}=26$ Brangus) had a mean age of 131 days (range of 84-180 days of age) at castration on June 16, 2010, and June 17, 2010. All calves were weighed once per month beginning in May until weaning in August. The experiment took place at the University of Florida Boston Farm-Santa Fe River Ranch Beef Research Unit. Cow-calf pairs had ad libitum access to hay with co-product supplement during the winter months (December 2009 through April 2010), and were maintained on bahiagrass pasture during the remainder of the trial period.

\section{Florida Outcome}

At the beginning of the trial, calf birth weights (Table 1) were similar among castration treatments. However, Brangus calves tended to be heavier at birth than Angus calves. At the conclusion of the trial, average weaning weight across castration treatments was $454 \pm 11.4 \mathrm{lbs}$, which was similar across treatments. Brangus calves tended to be heavier at weaning than Angus calves. In addition, weight per day of age at weaning and adjusted 205-d weaning weight were similar among treatments. Brangus calves had greater adjusted 205-d weaning weights compared to Angus calves. There was no breed by castration interaction between early and late castration treatments for any of the measurement points in this study, which suggests that the effect of time at castration was not different between Angus and Brangus calves. 
No differences were observed in body weight change and average daily gain (Table 1 ) during the trial period. When comparing calf body weights for May (282 lbs), no differences were observed between the early and late castration treatments. This implies that calves castrated at or near birth overcame any potential growth delays related to castration by the time the body weight measurements were initiated. Additionally, early castrates did not seem to experience any significant disadvantage in growth because of the treatment throughout the trial period.

Since both early and late castration treatments were performed prior to weaning and the onset of puberty, these results would seem reasonable. The concept underlying delayed castration is to leave male calves intact long enough to capture the benefits of endogenously secreted androgens known to stimulate growth in animals (Gortsema et al. 1974). However, to capture the full benefit, castration would most likely need to be delayed until calves approach puberty. As calves reach that point, they would have the ability to secrete enough endogenous testosterone to create significant differences in weight and growth performance. The comparable pubertal status of the treatment groups in this study likely contributed to the similar weaning weights and growth measures between the early and late castrates.

\section{Conclusion}

No differences in calf growth rates were observed in early compared to late castration. Calf performance results from this trial and others suggest that producers have some flexibility in determining when to implement castration. Producers should recognize that castration at or shortly after birth will not have a detrimental effect on calf performance or ultimate weaning weight. Equally important, producers should also realize that delaying castration until calves are approximately 131 days old will not bring added pounds at weaning despite some producer philosophies and marketing claims that endorse such management practices.

\section{References}

Avent, R. K., C. E. Ward, and D. L. Lalman. 2002. Economic Value of Preconditioning Feeder Calves. Extension Fact Sheet AGEC-583. Stillwater: Oklahoma State University.

Bailey, C. M., C. L. Probert, and V. R. Bohman. 1966. "Growth Rate, Feed Utilization and Body Composition of Young Bulls and Steers.” J. Anim. Sci. 25(1):132-137.

Berry, B. A., W. T. Choat, D. R. Gill, C. R. Krehbiel, R. A. Smith, and R. L. Ball. 2001. Effect of Castration on Health and Performance of Newly Received Stressed Feedlot Calves. Oklahoma State Research Report. Stillwater: Oklahoma State University. http://www.ansi.okstate.edu/research/ research-reports-1/2001/2001\%20Berry\%20Research\%20 Report.pdf.

Bretschneider, G. 2005. "Effects of Age and Method of Castration on Performance and Stress Response of Beef Male Cattle: A Review." Livestock Prod. Sci. 97(2-3):89-100.

Cundiff, L. V., R. L. Willham, and C. A. Pratt. 1966. "Effects of Certain Factors and Their Two-Way Interactions on Weaning Weight in Beef Cattle." J. Anim. Sci. 25:972-982.

Glimp, H. A., M. E. Dikeman, H. J. Tuma, K. E. Gregory, and L. V. Cundiff. 1971. "Effect of Sex Condition on Growth and Carcass Traits of Male Hereford and Angus Cattle." J. Anim. Sci. 33(6):1242-1247.

Gortsema, S. R., J. A. Jacobs, R. G. Sasser, T. L. Gregory, and R. C. Bull. 1974. "Effects of Endogenous Testosterone on Production and Carcass Traits in Beef Cattle." J. Anim. Sci. 39(4):680-686.

King, B. D., R. D. H. Cohen, C. L. Guenther, and E. D. Janzen. 1991. "The Effect of Age and Method of Castration on Plasma Cortisol in Beef Calves." Can. J. Anim. Sci. 71:257-263.

Klosterman, E. W., L. E. Kunkle, P. Gerlaugh, and V. R. Cahill. 1954. "The Effect of Age of Castration upon Rate and Economy of Gain and Carcass Quality of Beef Calves." J. Anim. Sci. 13:817-825.

Knight, T. W., G. P. Cosgrove, M. G. Lambert, and A. F. Death. 1999. "Effects of Method and Age at Castration on Growth Rate and Meat Quality of Bulls." New Zealand J. of Agriculture Res. 42:255-268.

Knight, T. W., G. P. Cosgrove, A. F. Death, and C. B. Anderson. 2000. "Effect of Age of Pre- and Post-Pubertal Castration of Bulls on Growth Rates and Carcass Quality." New Zealand J. of Agriculture Res. 43(4):585-588.

Lehmkuhler, J. 2003. Castration of Beef Calves: Early or Late? Madison: University of Wisconsin-Madison. http:// www.uwex.edu/ces/animalscience/beef/documents/2003Ca strationofBeefCalves.pdf.

Looper, M. L., J. M. Burke, L. J. McBeth, C. R. Krehbiel, R. Flores, C. F. Rosenkrans, and G. E. Aiken. 2005. "Growth, Feedlot Performance, and Carcass Characteristics of Angus 
and Charolais-Sired Calves Castrated at Birth or Weaning." AAES Res. Series 535:109-111.

Lyons-Johnson, D. 1998. "Earlier Castration Reduces Stress.” Agriculture Research Magazine. USDA 46(8):15.

Marlowe, T. J., and J. A. Gaines. 1958. "The Influence of Age, Sex, and Season of Birth of Calf, and Age of Dam on Preweaning Growth Rate and Type Score of Beef Calves." J. Anim. Sci. 17(3):706-713.

Micol, D., M. P. Oury, B. Picard, J. F. Hocquette, M. Briand, R. Dumont, D. Egal, R. Jailler, H. Dubroeucq, and J. Agabriel. 2009. "Effect of Age at Castration on Animal Performance, Muscle Characteristics and Meat Quality Traits in 26-Month-Old Charolais Steers." Livestock Sci. 120(1-2):116-126.
Schulz, L., K. Dhuyvetter, K. Harborth, and J. Waggoner. 2010. Factors Affecting Feeder Cattle Prices in Kansas and Missouri. Department of Agricultural Economics, Kansas State University. http://www.agmanager.info/livestock/budgets/production/beef/Factors\%20Affecting\%20Feeder\%20 Cattle\%20Prices\%20\%28Nov2009--RevisedMar2010\%29. pdf.

Stafford, K. J., and D. J. Mellor. 2005. “The Welfare Significance of the Castration of Cattle: A Review." New Zealand Vet. J. 53(5):271-278.

United States Department of Agriculture, National Animal Health Monitoring System (USDA-NAHMS). 2008. Part I: Reference of Beef Cow-Calf Management Practices in the United States, 2007-08. \#N512-1008. Fort Collins, CO: USDA, APHIS, National Animal Health Monitoring System.

Table 1. The Effect of Age at Castration on Calf Growth Performance

\begin{tabular}{|c|c|c|c|c|}
\hline \multicolumn{5}{|c|}{ Treatment $^{1}$} \\
\hline Item & Early & Late & $\mathrm{SE}^{2}$ & P-Value \\
\hline Birth weight, lb. & 80 & 81 & 2.4 & 0.83 \\
\hline Weaning weight, lb. & 456 & 452 & 11.5 & 0.76 \\
\hline Weight per day of age, lb. & 2.44 & 2.35 & 0.06 & 0.24 \\
\hline Adjusted 205-d weaning weight, lb. & 512 & 504 & 8.9 & 0.51 \\
\hline \multicolumn{5}{|l|}{ Body weight change, lb. } \\
\hline May to June & 77 & 75 & 4.7 & 0.79 \\
\hline June to July & 86 & 82 & 3.6 & 0.40 \\
\hline July to August & 100 & 96 & 4.3 & 0.55 \\
\hline May to August & 176 & 171 & 5.9 & 0.49 \\
\hline Birth to Weaning & 376 & 371 & 10.8 & 0.71 \\
\hline \multicolumn{5}{|l|}{ Average daily gain, lbs/day } \\
\hline May to June & 2.32 & 2.27 & 0.14 & 0.79 \\
\hline June to July & 2.06 & 1.96 & 0.09 & 0.39 \\
\hline July to August & 1.65 & 1.59 & 0.07 & 0.54 \\
\hline May to August & 1.88 & 1.82 & 0.06 & 0.49 \\
\hline Birth to Weaning & 2.00 & 1.92 & 0.05 & 0.19 \\
\hline
\end{tabular}

